\title{
Смирнов А.Ю. \\ Специфика преподавания общественных дисциплин иностранным специалистам в военном авиационном вузе
}

Филиал Военного учебно-научного иеентра Военно-воздушных сил «Военно-воздушная академия им. проф. Н.Е. Жуковского и Ю.А. Гагарина»

(Россия, Сызрань)

doi: 10.18411/trnio-10-2021-21

\section{Аннотация}

Статья посвящена выявлению специфики преподавания учебного материала иностранным военным специалистам (ИВС) на кафедре гуманитарных и социальноэкономических дисциплин в авиационном военном вузе Министерства Обороны Российской Федерации. Особое внимание автор уделяет рассмотрению проблем, возникающих в ходе реализации данного процесса, также предлагаются варианты их решения или минимизации негативного воздействия, которые используются преподавателями кафедры на практике.

Ключевые слова: обучение иностранных военных специалистов, общественные дисциплины, языковая грамотность, летно-техническая направленность.

\section{Abstract}

The article is devoted to the analysis of the specifics of teaching educational material to foreign military specialists (IVS) at the Department of Humanities and Socio-economic Disciplines at the aviation military university of the Ministry of Defense of the Russian Federation. The author pays special attention to the problems that arise during the implementation of this process. It also offers options for ways to solve them or minimize the negative impact, which are used by teachers of the department in practice.

Keywords: training of foreign military specialists, social disciplines, language literacy, flight-technical orientation.

В Указе Президента Российской Федерации №204 от 7 мая 2018 года «О национальных целях и стратегических задачах развития Российской Федерации на период до 2024 года» одной из целей, поставленных перед Правительством РФ в области образования, являлась: «обеспечение глобальной конкурентоспособности российского образования, вхождение Российской Федерации в число 10 ведущих стран мира по качеству общего образования». Для ее достижения необходимо к 2024 году увеличить не менее чем в два раза количества иностранных граждан, обучающихся в образовательных организациях высшего образования и научных организациях [1].

Задача почти невыполнимая, но не для военных вузов. Высокий рейтинг военного образования в России по мировым стандартам был всегда. Всплески и спады военного сотрудничества никак не влияли на качество российского оружия, популярность которого была есть и будет на высоком мировом уровне. Возникает вопрос: «Где и как лучше всего научиться эффективно его эксплуатировать?». Ответ однозначен - в стране-изготовителе, поставщике вооружения.

В нашем филиале Военного учебно-научного центра Военно-воздушных сил «Военновоздушная академия им. проф. Н.Е. Жуковского и Ю.А. Гагарина» в г. Сызрани (бывшее Сызранское высшее военное авиационное училище летчиков) за период его 81-летнего существования прошли подготовку иностранные военные специалисты более 40-а государств. Сегодня филиал ВУНЦ ВВС «ВВА» в г. Сызрани - это единственный военный авиационный вуз, осуществляющий подготовку летного состава вертолетной авиации всех силовых ведомств Российской Федерации. В настоящее время здесь проходят обучения иностранные военные специалисты из 28 государств. География расположения стран заказчиков на обучение охватывает практически все заселенные людьми континенты за исключением Австралии. Основных направлений обучения в военном вузе пять. Высшее 
образование представлено специальностью «Летная эксплуатация авиационных комплексов», средний профиль осуществляет подготовку авиационных техников по четырем основным системам авиационной техники. Весь личный состав ИВС, различающийся по личностному менталитету, социально-культурной направленности, религиозному вероисповеданию проходят обучение на кафедре гуманитарных и социально-экономических дисциплин вуза.

До 2019 года основным нормативно-правовым актом, регулирующим процесс обучения ИВС в военных вузах Российской Федерации, был Приказ МО РФ №575 от 10 декабря 2000 года «Инструкция об организации подготовки национальных военных кадров и технического персонала иностранных государств в воинских частях и организациях Вооруженных Сил Российской Федерации» [5]. С 2019 года вся организация и работа с иностранными военными специалистами ведется на основании новых документов министерства обороны РФ, имеющих минимум гриф ДСП (для служебного пользования). Основное отличие, отразившееся на процесс обучения, проявилось в том, что ИВС из стран, входящих в состав ОДКБ, проходят учебный процесс в составе российских учебных групп.

Учебный план функционирования вуза сформирован под российский контингент курсантов. Основные гуманитарные дисциплины преподаются на первом и втором курсах обучения. В данный период и проявляется основная проблема обучения ИВС. Она заключается в трудности усвоения иностранными курсантами учебного материала по следующим дисциплинам: История, Культурология, Философия, Правоведение, Психология и педагогика и их основ в русле среднего профиля обучения. Все это связанно с непониманием категориального аппарата данных дисциплин и его многозначного сущностного толкования на русском языке.

Сроки обучения ИВС в авиационном военном вузе зависят от уровня образования. Высший профиль - 6 лет (российские курсанты и ближнее зарубежье - 5 лет), средний профиль - 4 года (ближнее зарубежье - 3 года). Для иностранных военнослужащих, кроме стран ближнего зарубежья, выделяется дополнительный год обучения для изучения специализированного русского языка. В научных кругах данная деятельность называется допрофессиональной языковой подготовкой [2, с. 327]. Её специфика в авиационном учебном заведении заключается в изучении терминологии летно-технической направленности. Понятийно-категориальный аппарат обществознания иностранные военные специалисты не проходят. Отсюда и возникают проблемы усвоения дисциплин, преподаваемых на кафедре ГиСЭД.

Основной целью страны-заказчика, отправившей на обучение в военные вузы своих представителей и заплатившей за это валютой, является подготовка качественного военнопрофессионального специалиста для своих вооруженных сил. Не философа или психолога, а офицера-профессионала. Поэтому принято считать, что гуманитарный курс дисциплин необходим для усиления языковой подготовки ИВС, их успешной инкультурации и социализации в новых условиях [3, с. 140].

Количественно-качественный состав учебных групп курсантов специального факультета (ИВС) разнообразный и зависит от направления специализации. В одних группах может быть 1-2 человека, в других - 10 и более. На лекционное занятие по дисциплинам кафедры ГиСЭД, как правило, собираются все группы одного курса. Поток может составлять до 25 человек и более. По каким критериям ведется отбор кандидатов на обучение в российских военных вузах странами-заказчиками непонятно до сих пор. Способности к усвоению учебного материала у представителей даже одной страны резко отличаются. От практически ничего не знающих до очень хорошо подготовленных, зачастую превышающих уровень знаний российских курсантов. Причем нет зависимости от принадлежности слушателей к странам дальнего зарубежья или ближнего. Очень часто представители из бывших стран СССР приходят с полным незнанием русского языка, а год на его изучение им не предусмотрен. Отсюда и вытекают все сложности и проблемы преподавания, начиная с 
подачи учебного материала на лекционном занятие и контроле его усвоения на семинарских и практических занятиях.

В научных работах и руководящих документах по данной проблеме, как правило, звучат общие фразы: углубить..., расширить..,, изменить подход..., особый отбор преподавателей и т.д. В современных условиях, с все ужесточающимися требования к количеству часов аудиторной нагрузки, каждый преподаватель является «многостаночником». Качественно подготовиться к проведению занятий по шести дисциплинам, а иногда и более, физически невозможно. Все про это знают, но никто ничего не предпринимает. П. С. Тенилов в своей диссертации на соискание ученой степени кандидата педагогических наук рекомендует пути повышения эффективности процесса обучения ИВС. Среди них:

— органам военного управления пересмотреть нормы аудиторной нагрузки для преподавателей работающих с ИВС, так как подготовка к занятиям с иностранцами требует больше времени [4, с. 21];

- в рабочие программы и тематические планы для работы с ИВС внести изменения в связи с малочисленностью их учебных групп (например, в малочисленных группах целесообразно планировать семинары и практические занятия меньшей продолжительностью по сравнению с установившейся в отечественной высшей военной школе) [4, с. 22].

По нашему мнению, данные рекомендации из области фантастики. У нас на кафедре весь профессорско-преподавательский состав проводит занятия с ИВС. Изменение аудиторной нагрузки приведет к необходимости введения новых штатных единиц, а на это никто не пойдет. На всех кафедрах, да и во всех военных вузах ситуация такая же. Вторая рекомендация еще менее реальная, чем первая. Непонятно, что автор диссертации подразумевает. Ввести для ИВС 45-минутные уроки как в школе или убрать 4-часовые семинары, заменив их на 2-х часовые? Опять возникает вопрос, а куда девать остальные часы? Процентное распределение между лекционными и групповыми занятиями никто не отменял. Да и разработка отдельных учебных программ и тематических планов для ИВС увеличит и без того большую «бумаготворческую» деятельность преподавателей.

В связи со всеми вышеизложенными проблемами, на нашей кафедре ГиСЭД выбран оптимальный (с нашей точки зрения) подход к организации и проведению занятий по гуманитарному направлению с иностранными военными специалистами.

1. Лекционное занятие проводится в два этапа. Первоначально с помощью мультимедйных средств доводится учебный материал с ответами на возникающие вопросы. Конспектирование в рабочие тетради не ведется. Далее каждому курсанту выдается раздаточный материал, который содержит всю основную информацию по лекции (название темы, учебные вопросы, задание на самоподготовку, основные определения по каждому вопросу), то есть все то, что обучаемый должен был бы законспектировать проводись занятие по классической форме. Раздаточный материал можно заменять учебными пособиями, если они выполнены специально для этой цели и не несут дополнительную, не воспринимаемую ИВС информацию. Выданный материал остается на руках у курсантов, и они продолжают его отрабатывать в часы самоподготовки.

2. На семинарском или практическом занятие раздаточный материал собирается преподавателем и начинает дискуссию по возникшим вопросам и вопросам занятия (если это удается организовать). После этого каждому обучающемуся выдается письменное задание по теме, как правило, это небольшой тест, на вопросы которого ИВС должены ответить. Разрешается пользоваться только конспектом.

Основу данного подхода составляет наличие и качественное ведение иностранным военным специалистом конспекта лекций по дисциплине. Мотивирование на работу 
обучаемого достигается тем, что на всех видах контроля (текущий, рубежный, промежуточный) ему разрешается пользоваться рабочей тетрадью. От качества ее заполнения зависит и оценка за занятии.

Данная методика подходит для проведения занятий только по гуманитарному направлению. Для дисциплин военно-профессиональной подготовки она непригодна.

$$
* * *
$$

1. Президент подписал Указ «О национальных целях и стратегических задачах развития Российской Федерации на период до 2024 года» [Электронный ресурс]. Режим доступа: http://www.kremlin.ru/events/president/news/57425. Дата обращения: 15.09.2021.

2. Скибо Т.Ю. Социально-психологический аспект подготовки иностранных военных специалистов в вузах Министерства обороны Российской Федерации // Воздушно-космические силы. Теория и практика. Учредители: ВУНЦ ВВС «ВВА им. проф. Н.Е. Жуковского и Ю.А. Гагарина» (Воронеж).- №1. - 2017. - С. 326-332.

3. Сушко А.В., Нагаев И.Б., Иоаниди А.Ф., Лидер Н.В. Восприятие учебного материала дисциплины «История России» гражданами иностранных государств, обучающимися в военно-учебных заведениях Российской Федерации: проблемы и пути ее решения // Омский научный вестник. - №3 (109). - 2012. - С. 140-144.

4. Тенилов П.С. Обучение иностранных военнослужащих на основе принципа доступности: Автореферат дис. ... уч. ст. канд. пед. наук. - Москва, 2018. - 24 с.

5. Приказ Министра обороны РФ от 10.12 .2000 г. №575 [Электронный ресурс]. Режим доступа: https://normativ.kontur.ru/document?moduleId=1\&documentId=151098. Дата обращения: 17.09.2021.

Стародумов Л.Л.

Обучение информатике в вузе с учетом доминирующего вида мышления ФГБОУ ВПО «Сочинский государственный университет» (Россия, Сочи)

doi: 10.18411/trnio-10-2021-22

\section{Аннотация}

В статье рассматриваются педагогические условия обучения студентов информатике на основе учета доминирующего у них вида мышления.

Ключевые слова: индивидуализация обучения, компьютерные технологии.

\section{Abstract}

The article considers the pedagogical conditions of training of students of computer science on the basis of the dominant they have kind of thinking.

Keywords: individualization of training, computer technologies.

Специфика информатики как предмета такова, что для успешного ее усвоения необходим достаточно хороший уровень развития познавательной сферы студента, т. е. должны быть сформированы мыслительные операции обобщения, классификации, подведения понятия под класс, сериации и т.д.; высокий уровень развития учебной деятельности, который характеризуется сформированностью всех сторон этой деятельности: мотивационной, операциональной, контрольно-оценочной. При этом и все остальные психические процессы - восприятие, память, внимание, произвольность поведения - должны находиться на достаточно высоком уровне.

Информатика, как наука о наиболее оптимальных способах получения, обработки, хранения и передачи информации, может оказать значительную помощь в развитии мышления обучающегося. При решении алгоритмических задач формируется теоретический обобщенный стиль мышления, который опирается на содержательное обобщение предметов и явлений, в отличие от эмпирического, связанного с формальным обобщением. Но для этого при обучении информатике необходимо учитывать уровень развития психических процессов, в первую очередь мышления. 